\title{
Competitive interactions between the invasive green alga Codium fragile ssp. tomentosoides and native canopy-forming seaweeds in Nova Scotia (Canada)
}

\author{
Robert E. Scheibling*, Patrick Gagnon \\ Department of Biology, Dalhousie University, Halifax, Nova Scotia B3H 4J1, Canada
}

ABSTRACT: Two concurrent 2 yr experiments were conducted along the Atlantic coast of Nova Scotia (1) to examine competitive interactions between the invasive green alga Codium fragile ssp. tomentosoides and canopy-forming native seaweeds, particularly the dominant kelps (Laminaria longicruris and L. digitata) and opportunistic algae (Desmarestia viridis and D. aculeata), and (2) to identify conditions enabling the establishment and persistence of $C$. fragile. In the first experiment, Laminaria spp. and/or Desmarestia spp. were either removed or left intact (in an orthogonal factorial design) to examine their effect on C. fragile. At the end of the experiment, cover, density, and biomass of $C$. fragile did not differ significantly among treatments, although mean density was up to 2 times greater in plots where kelp was removed than in control plots. While removal of kelp positively affected growth of $C$. fragile (up to $12 \mathrm{~cm} \mathrm{mo}^{-1}$ ) during the first year, growth was similar among treatments in the second year, when kelps were smaller and Desmarestia spp. were virtually absent (following decimation of native seaweeds by the invasive bryozoan Membranipora membranacea). Survival of marked individuals of $C$. fragile was high in all treatments in the first year (85 to $100 \%$ ), but dropped during winter in the second year (40 to $60 \%$ ). In the second experiment, the effect of stands of $C$. fragile on recolonization by Laminaria spp. and Desmarestia spp. was examined by removing $C$. fragile in both Pulse and Press removal treatments. At the end of the experiment, density of Laminaria spp. in the Press treatment was more than 4 times higher than in the Pulse treatment. Dense stands of C. fragile in control plots inhibited recruitment of kelps and other seaweeds, and survival of marked thalli of $C$. fragile over 9 mo was high $(90 \%)$. We conclude $C$. fragile exhibits competitive advantages over native seaweeds through opportunistic exploitation of disturbancegenerated gaps within kelp beds. Once established as dense meadows, $C$. fragile prevents re-colonization by kelp and persists as the dominant canopy-forming seaweed for prolonged periods.

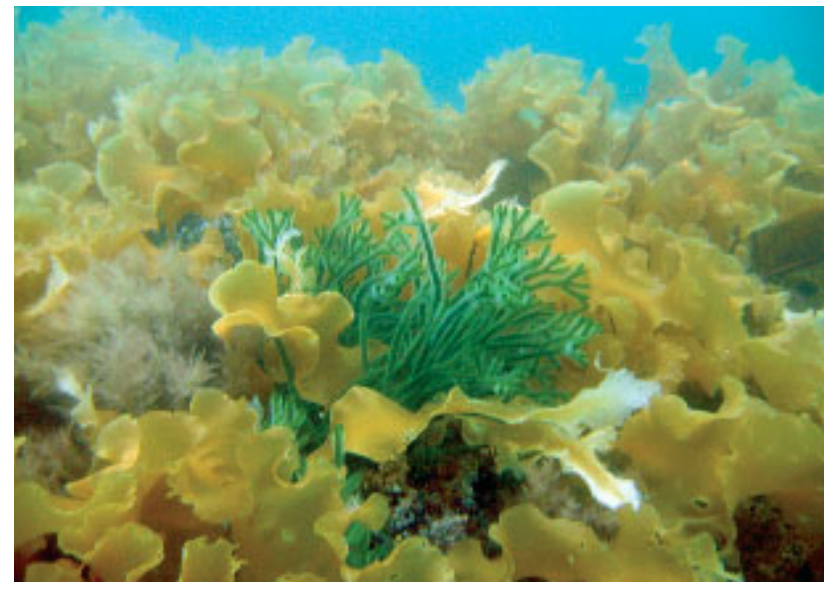

Along the Atlantic coast of Nova Scotia, the introduced green alga Codium fragile ssp. tomentosoides opportunistically exploits disturbance-generated gaps in kelp beds (above) and, once established, forms dense meadows that inhibit subsequent re-colonization by kelps and other native seaweeds.

Photo: Robert Scheibling

KEY WORDS: Invasive species - Competition . Community dynamics · Facilitation · Codium fragile ssp. tomentosoides - Kelp - Membranipora membranacea . Species interactions Resale or republication not permitted without written consent of the publisher

\section{INTRODUCTION}

As accidental introductions of non-native species to coastal ecosystems accelerate on a global scale, there is a growing and urgent concern about the potential threats to biodiversity and the integrity of natural marine communities (Carlton 1992, MacIsaac 1996, Ruiz et al. 1997, Cohen \& Carlton 1998, Carlton 1999, 
Bax et al. 2003, Strayer et al. 2004). Studies of marine invasions have focused largely on documenting the spread of non-native species by human activities or characterizing the attributes of successful invaders over a variety of spatial and temporal scales (e.g. Carlton \& Scanlon 1985, Meinesz \& Hesse 1991, Jaubert et al. 2003, Castilla et al. 2005). More recently, attention has been directed towards understanding biotic interactions that mediate the establishment, spread and persistence of introduced marine species. Biotic interactions between native and introduced species are often inferred from correlational evidence (e.g. Lambert et al. 1992, Grosholz \& Ruiz 1996, Chapman 1999, Scheibling \& Anthony 2001). Rigorous experimental testing of causal mechanisms has lagged behind observational studies of pattern (but see Reusch \& Williams 1999, Grosholz et al. 2000, Britton-Simmons 2004, Kushner \& Hovel 2006).

Growing recognition of the importance of facilitative interactions as a structuring force in marine and terrestrial ecosystems has called into question a more traditional theoretical foundation that emphasizes the role of negative interactions (predation and competition) in population and community ecology (see reviews by Callaway 1995, Bruno \& Bertness 2001). Rooted in a contemporary scientific current that strives to integrate effects of both negative and facilitative interactions is the view that invasive species (like indigenous ones) not only compete for resources within their introduced range, but may also benefit from the presence of other introduced species that increase the likelihood of their survival and establishment, and possibly the magnitude of their impact. Termed 'invasional meltdown' by Simberloff \& Von Holle (1999), the notion of facilitative interactions among invaders counterpoints the traditional 'biotic resistance' paradigm (sensu Elton 1958) that invasion failure results from inhibition by resident species. Between these extremes lies a range of direct and indirect species interactions with various invasional outcomes. Numerous published accounts support both the invasional meltdown (e.g. Ricciardi 2001, Wonham et al. 2005, Parker et al. 2006) and biotic resistance paradigms (e.g. Stachowicz et al. 1999, Ruiz et al. 2000, Britton-Simmons 2006). However, the frequency of occurrence of invasional meltdown may be greater than suggested by the literature (Simberloff \& Von Holle 1999).

In coastal marine habitats, introduced macrophytes (i.e. seaweeds and seagrasses) have often been associated with changes in biodiversity and community structure. In the Mediterranean Sea alone, at least 61 species of macrophytes (Rhodophyta, Phaeophyceae, Chlorophyta, and Spermatophyta) are introduced, and these have had varying ecological impacts (Verlaque 1994, Ribera \& Boudouresque 1995, Boudouresque
\& Verlaque 2002). Although many non-indigenous macrophytes are assimilated into host communities without obvious affect, others have caused major alterations in community structure through competitive displacement or exclusion of native species. Well documented examples include the tropical green algae Caulerpa taxifolia and C. racemosa in the Mediterranean Sea and southeastern Australia (Meinesz \& Hesse 1991, Verlaque \& Fritayre 1994, Balata et al. 2004, York et al. 2006), the Asian seagrass Zostera japonica along the western coast of the USA (Posey 1988), the Asian kelp Undaria pinnatifida (Laminariale) in central Patagonia (Casas et al. 2004) and Tasmania (Valentine \& Johnson 2003), and the Asian brown alga Sargassum muticum (Fucale) in western Europe and western USA (Staehr et al. 2000, Britton-Simmons 2004, Sanchez et al. 2005, Buschbaum et al. 2006).

In the northwest Atlantic, the green alga Codium fragile ssp. tomentosoides presents a striking example of widespread invasion by a subtidal seaweed. Native to Japan, C. fragile was first observed along the east coast of North America in Long Island Sound (New York) in the mid 1950s (Carlton \& Scanlon 1985, Trowbridge 1998). Its geographical range has since expanded considerably, with a current estimated distribution from North Carolina (USA) to southern Québec (Canada) (Bird et al. 1993, Garbary et al. 1997, Mathieson et al. 2003). In the Gulf of Maine (USA) and along the Atlantic coast of Nova Scotia (Canada), $C$. fragile has become the dominant canopy species at sites once dominated by luxuriant kelp beds (mainly Laminaria spp.) (Harris \& Tyrrell 2001, Chapman et al. 2002, Mathieson et al. 2003). Mechanistic explanations of the replacement of kelp by $C$. fragile in this region include (1) removal of grazing pressure by the urchin Strongylocentrotus droebachiensis after mass mortality caused by disease (Scheibling \& Anthony 2001) and (2) major reductions in kelp canopy caused by outbreaks of a non-indigenous, epiphytic bryozoan Membranipora membranacea that result in increased fragmentation of fronds during periods of strong wave surge (Scheibling et al. 1999, Chapman et al. 2002, Levin et al. 2002).

Inferences about causal mechanisms are largely based on observations over the last 2 decades of changing patterns of distribution and abundance of native and introduced species in Nova Scotia (Chapman et al. 2002) and the Gulf of Maine (Berman et al. 1992, Harris \& Tyrrell 2001, Mathieson et al. 2003). Levin et al. (2002) provide evidence from small-scale transplantation studies of positive interactions between invasive species by showing that kelp survival is lowest in the presence of both Codium fragile and Membranipora membranacea. However, the role of competition in enabling (1) the establishment of 
C. fragile within host communities, (2) the displacement of native algal species (including the competitively dominant, canopy-forming kelps), and (3) the persistence of $C$. fragile, is not well understood. One facet of interaction - the effect of kelp on C. fragileremains unknown, although its assessment is critical to unequivocally resolve competitive interactions between the alien and native seaweed species.

In this study, we report on the results of 2 concurrent field experiments conducted between 1997 and 2000 to examine competitive interactions between Codium fragile and canopy-forming native seaweeds: the dominant perennial kelps (Laminaria longicruris and L. digitata) and annual (Desmarestia viridis) and perennial ( $D$. aculeata) plumose brown algae. These experiments mimic defoliation of native seaweeds by Membranipora membranacea and disturbance within $C$. fragile meadows to identify conditions enabling the establishment and persistence of $C$. fragile. We show that $C$. fragile exhibits competitive advantages over native seaweeds in its introduced range through opportunistic exploitation of disturbance-generated gaps within native kelp beds.

\section{MATERIALS AND METHODS}

Study site and macroalgal community dynamics. The study site is located in the lee of Little Duck Island $\left(44^{\circ} 22^{\prime} \mathrm{N}, 64^{\circ} 11^{\prime} \mathrm{W}\right)$ at the mouth of Mahone Bay, Nova Scotia, and is semi-protected from the predominant southwesterly swell. The substratum consists of a series of basaltic ledges and troughs, extending from the intertidal to ca. $10 \mathrm{~m}$ depth (below mean lower low water), where the rock outcrops grade to a cobble bed. The dynamics of sea urchin (Strongylocentrotus droebachiensis) and macroalgal populations at this site have been the focus of a number of studies since 1992 (e.g. Scheibling \& Hennigar 1997, Meidel \& Scheibling 1998, Scheibling et al. 1999, Balch \& Scheibling 2000), which provide a contextual baseline for examining interactions between Codium fragile and native seaweeds that influence the pattern and rate of invasion.

In 1992, a luxuriant kelp bed covered the rocky substratum down to ca. $8 \mathrm{~m}$ depth (below mean low water), where a dense front of sea urchins was advancing onshore from deeper regions and destructively grazing all seaweeds (Scheibling et al. 1999). Laminaria longicruris was the dominant canopy-forming kelp throughout all but the shallowest areas $(<2 \mathrm{~m}$ depth) where it was replaced by L. digitata. Large plumose brown algae (Desmarestia aculeata and D. viridis) and annual kelp (Saccorhiza dermatodea) occurred in metre-scale gaps within the Laminara bed. An understorey turf consisted of branching coralline algae (Corallina officinalis) and foliose and filamentous red algae (Ceramiun rubrum, Ptilota serrata, Plumaria plumosa, Chondrus crispus, Palmaria palmata; Scheibling et al. 1999).

Codium fragile ssp. tomentosoides was first established at shallow depths $(<5 \mathrm{~m})$ after recurrent outbreaks of Membranipora membranacea in 1993 and 1994 decimated the kelps at this site (Scheibling et al. 1999). In deeper waters, the kelp bed (mainly Laminaria longicruris) regenerated by 1995 through recruitment and growth of juvenile sporophytes (Scheibling et al. 1999). However, recurrent infestations of M. membranacea continued to erode the remaining kelps and, coupled with an increased supply of $C$. fragile propagules from the shallow stands, probably facilitated the offshore spread of the invasive alga at Little Duck Island. Outbreaks of disease caused mass mortality of urchins in 1995 (Scheibling \& Hennigar 1997) and enabled seaweeds, including $C$. fragile, to colonize the barrens formed by intensive grazing in the deeper regions of this site (below $6 \mathrm{~m}$ ). C. fragile progressively increased in cover and thallus size along with native seaweeds (Laminaria spp. and Desmarestia spp.) during the early stages of succession in 1996 and 1997 (Chapman et al. 2002).

Effect of native canopy-forming seaweeds on Codium fragile. The effect of kelp (Laminaria longicruris and L. digitata, hereafter Laminaria) and other canopy-forming brown algae (Desmarestia aculeata and $D$. viridis, hereafter Desmarestia) on the recruitment, growth, and survival of $C$. fragile ssp. tomentosoides (hereafter Codium) during succession in the former urchin barrens, was examined in a factorial experiment in which Laminaria (L) and/or Desmarestia (D) were removed (-) or left intact $(+)$ in 4 treatments: L-D+, L-D-, L+D-, L+D+ (control). In August 1997 , 2 yr after the sea urchin die-off, 16 plots of $1 \times 1 \mathrm{~m}$ were located within mixed stands of Laminaria, Desmarestia and Codium. The plots were selectively placed on relatively flat ledges within a $15 \times 50 \mathrm{~m}$ area at ca. $8 \mathrm{~m}$ depth $( \pm 0.5 \mathrm{~m})$. Four replicate plots of each of the 4 treatments were randomly assigned to the 16 plots. All individuals of Laminaria and/or Desmarestia were manually removed (similar to the effects of severe defoliation of native seaweeds by Membranipora membranacea) from each plot in a removal treatment, and from a $0.5 \mathrm{~m}$ wide buffer zone around a plot (i.e. a total of $4 \mathrm{~m}^{2}$ was cleared per plot); this was done once at the start of the experiment (20 August 1997) and at each sampling date thereafter (see Fig. 1). The plots were marked at all corners with small plastic floats suspended $1 \mathrm{~m}$ off the bottom. Care was taken by divers not to disturb Codium, or other non-manipulated algae, within or around the plots while the experiment was set up or on any sampling date. 
Percentage cover of Codium, Laminaria and Desmarestia was measured at about monthly intervals during the summer/autumn period of active growth of Codium, from August 1997 to October 1997 and from May 1998 to August 1999 in each experimental plot. The algal canopy in each plot was video-recorded using a diver-operated camera (Sony CCD-V801 Hi-8 video camera recorder in an Amphibico VH2000 housing). A $1 \mathrm{~m}$ wide framer attached to the housing was used to position the camera $0.6 \mathrm{~m}$ off the bottom. The diver aligned the framer with one side of a plot and swept across it, then reversed direction and repeated the sweep. This allowed duplicate records for analysis that were averaged to give a more precise estimate of the cover of thalli that moved in the surge. Percentage cover was analyzed by freezing frames centered in each plot (with a Sony EV-S900 VCR), projecting 100 regularly spaced points onto the frame, and counting the number of points overlying each algal type. Algal cover before (May 1997) and after (September 1999, and February, May, and August 2000) the experiment was recorded in 8 to 10 randomly positioned $1 \mathrm{~m}^{2}$ quadrats along a $50 \mathrm{~m}$ transect extending through the experimental area, and analyzed similarly.

Growth and survival of Codium were measured by monitoring individual thalli in each experimental plot. At the start of the experiment, 6 to 8 thalli were marked with a $2 \mathrm{~cm}$ diameter numbered plastic tag affixed with marine epoxy (Z-Spar) to the substratum $1 \mathrm{~cm}$ from the base of a thallus. Marked individuals were measured at 1 to 2 mo intervals during the summer/autumn growth season for Codium each year (i.e. September and October 1997; May, July, August, September, and October 1998; and February, June, and August 1999). Thallus length was measured with a plastic tape (1 $\mathrm{mm}$ accuracy) extended from the holdfast to the distal tips. Circumference was measured by loosely cinching the tape around the bushiest part of the thallus.

Density and biomass of Codium were measured at the end of the experiment (25 August 1999). Thalli in each experimental plot were manually removed at the holdfast, placed in a net bag, and returned to the shore in a plastic bin with seawater. Individual thalli (with a holdfast) were counted in each sample, and then pooled with any fragments detached during collection to measure fresh weight with a spring scale (25 $g$ accuracy).

Effect of Codium fragile on native canopy-forming seaweeds. The effect of established stands of Codium on recolonization by Laminaria and Desmarestia was examined by removing Codium in both Pulse and Press treatments. In August 1997, 10 plots of $1 \times 1 \mathrm{~m}$ were located within dense patches of Codium on relatively flat ledges within a $10 \times 50 \mathrm{~m}$ area extending alongshore of Little Duck Island at ca. $4 \mathrm{~m}$ depth
$( \pm 0.5 \mathrm{~m})$. The experimental site was situated ca. $80 \mathrm{~m}$ onshore (due North) from the site of the first experiment measuring the effect of native canopy-forming seaweeds on Codium (see above). For the Pulse removal treatment, Codium was removed from 5 of the 10 plots (and from a $0.5 \mathrm{~m}$ wide buffer zone around each plot) once at the start of the experiment (20 August 1997) and again after 1 yr (21 July 1998). The other 5 plots served as unmanipulated controls. For the Press removal treatment, Codium was manually removed from an additional 5 plots (located on similar substrata within the same experimental area) on 21 July 1998 and at approximately monthly intervals until the end of the experiment (25 August 1999).

The plots were marked and video-recorded as in the first experiment to measure percentage cover of the canopy at the start of the experiment (August 1997) and at approximately monthly intervals from April 1998 to August 1999. Canopy cover was also measured after the experiment in 8 to 10 randomly positioned $1 \mathrm{~m}^{2}$ quadrats along a $50 \mathrm{~m}$ transect extending through the experimental area in February, May, and August 2000. Density and biomass of Codium were measured in plots from which the species was experimentally removed (Pulse removal treatment, August 1997; Press removal treatment, July 1998) and from all plots at the end of the experiment. Density and biomass of native canopy-forming species (kelps and Desmarestia viridis) were measured in all treatments at the end of the experiment. All measurements were as described in the first experiment.

Growth and survival of Codium were measured in the control plots. In each of the 5 plots, the positions of 6 to 8 thalli were marked (as described in the first experiment), and measured in December 1998 and April, June and August 1999.

Statistical analyses. Changes in the percentage of canopy cover occupied by Codium, Laminaria and Desmarestia respectively, between treatments and sampling dates, were analyzed using repeated measures analysis of variance (ANOVA). Differences in density and biomass of these and other algal species at the end of each experiment were analyzed using 1- or 2-way ANOVA. Data were arcsine transformed as required to meet the assumption of homogeneity of variance (Levene's test, $\alpha=0.05$ ). Analyses were computed using Greenhouse-Geisser adjusted degrees of freedom when data did not meet the assumption of sphericity (Mauchly's test, $\alpha=0.05$ ). Growth of Codium (as length and circumference) in the first experiment was compared between treatments by 2-way ANOVA, and survival by 2 -way contingency table analysis, after pooling individuals over replicate plots. Numbers of surviving thalli in some plots were too low to permit robust testing of plot effects (e.g. nested ANOVA). 


\section{RESULTS}

\section{Native canopy-forming seaweeds limit the recruitment and growth of Codium fragile}

Removal of Laminaria (L) and/or Desmarestia (D) in experimental treatments (L-D+, L-D-, L+D-) generally increased the percent cover of Codium relative to control plots with both genera present (L+D+) (Fig. 1). Repeated measures ANOVA during the growing seasons for Codium in 1997 (August to October) and 1998
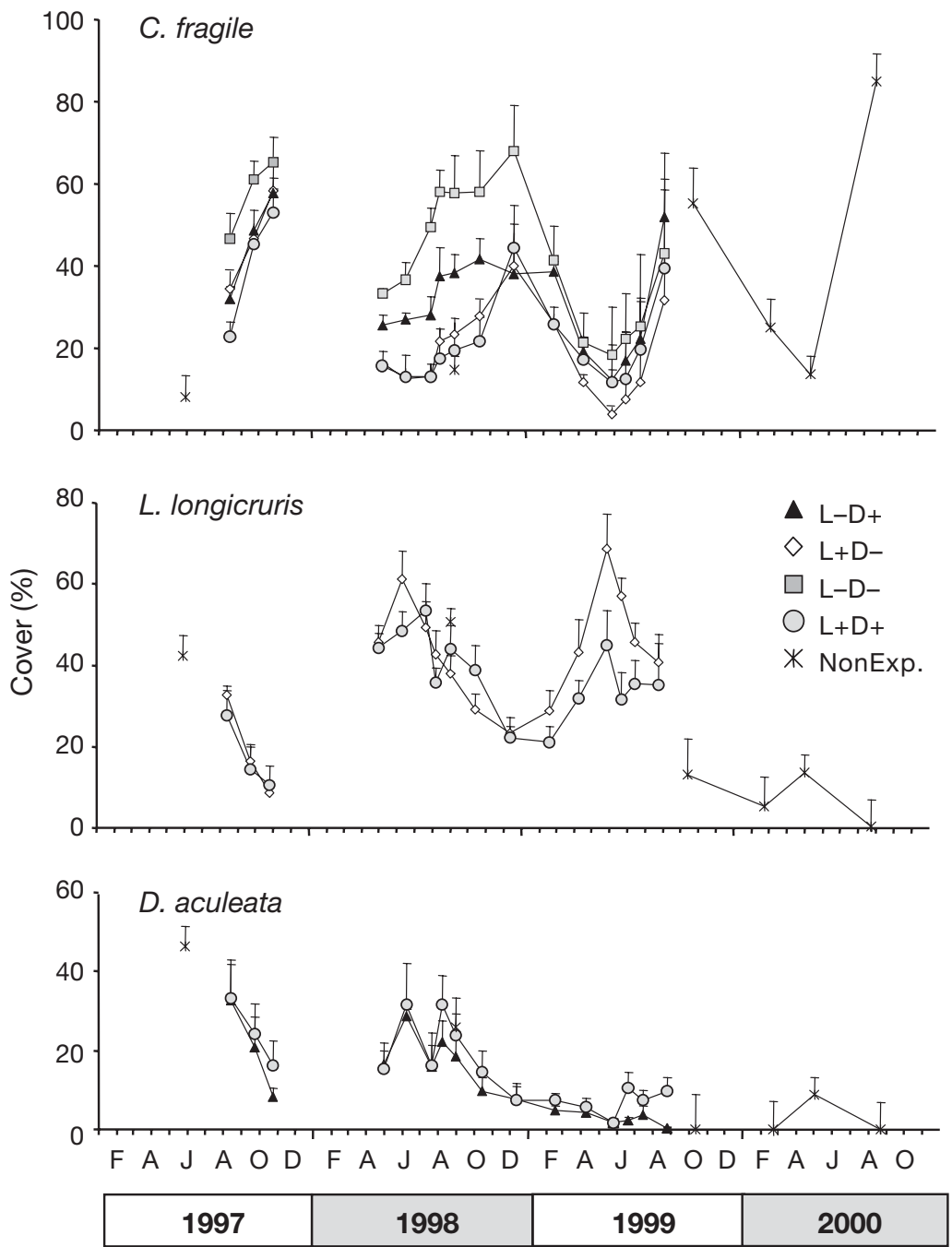

Fig. 1. Codium fragile, Laminaria longicruris and Desmarestia aculeata. Change in percentage canopy cover of $C$. fragile and of experimentally manipulated canopy-forming species ( $L$. longicruris, $D$. aculeata) in the 4 orthogonal treatments (L-D+, Laminaria removed; L+D-, Desmarestia removed; L-D-Laminaria and Desmarestia removed; L+D+, unmanipulated control), and the natural macroalgal assemblage (Non Exp., non-experimental random samples), at $8 \mathrm{~m}$ depth from May 1997 to August 2000. Data are mean + SE for 4 replicate $1 \mathrm{~m}^{2}$ plots per treatment ( 3 plots in 2 cases in 1998, 10 plots for non-experimental random samples). Cover of Laminaria and Desmarestia was ca. 0 in the respective removal treatments and is not shown here. Note that the maximum cover for all 3 species is $100 \%$
(May to October, excluding July because of missing data) showed significant effects on Codium cover of both treatments (1997: $F_{3,12}=3.7, \mathrm{p}=0.041 ; 1998$ : $\left.F_{3,11}=11.2, \mathrm{p}=0.001\right)$ and date $\left(1997: F_{2,24}=54.4, \mathrm{p}<\right.$ reatment in which both Laminaria and Desmarestia were removed (L-D-) was significantly higher than in the control or the treatment in which only Desmarestia was removed (L+D-, in 1998 only). In 1999 however, a similar analysis (April to August) indicated a significant effect of date $\left(F_{1.3,14.3}=16.4, \mathrm{p}=0.001\right)$, but no effect of treatment $\left(F_{3,11}=0.31, \mathrm{p}=0.817\right)$ and no interaction of treatment and date $\left(F_{3.9,14.3}=\right.$ $0.15, \mathrm{p}=0.956$ ). Within each year, the cover of Laminaria or Desmarestia in the treatment in which the respective alga was present (L+D- or L-D+) did not differ significantly from the control (Fig. 1) (repeated measures ANOVA: Laminaria, p > 0.10; Desmarestia, $\mathrm{p}>0.19$ ).

At the end of the experiment (August 1999), the mean density of Codium was lower in treatments where Laminaria was present than in those where it was removed (Fig. 2). This difference was greatest (by a factor of 2) between the treatment with Laminaria removed (L-D+, 37\%) and the control $(\mathrm{L}+\mathrm{D}+, 17 \%)$. However, there was no statistically detectable effect of the presence of either Laminaria or Desmarestia, and no significant interaction between these 2 factors, on either the density or biomass of Codium (2-way ANOVA, p > 0.20) (Fig. 2). There was also no difference in the density or biomass of Laminaria between the treatment with kelp (L+D-) and the control ( $t$-test, $\mathrm{p}>0.45)$; Desmarestia was absent or in very low abundance in all treatments by this time (Fig. 1).

Changes in mean size (length and circumference) of marked Codium within each experimental treatment (Fig. 3) reflect seasonal variation in vegetative growth (which is greatest in summer/autumn) and losses through fragmentation and dislodgment (which are greatest in winter). The mean size of thalli increased in all treatments in autumn 1997 (between September and October) and then decreased over winter/spring (between October 1997 and May 1998). There were no significant effects 

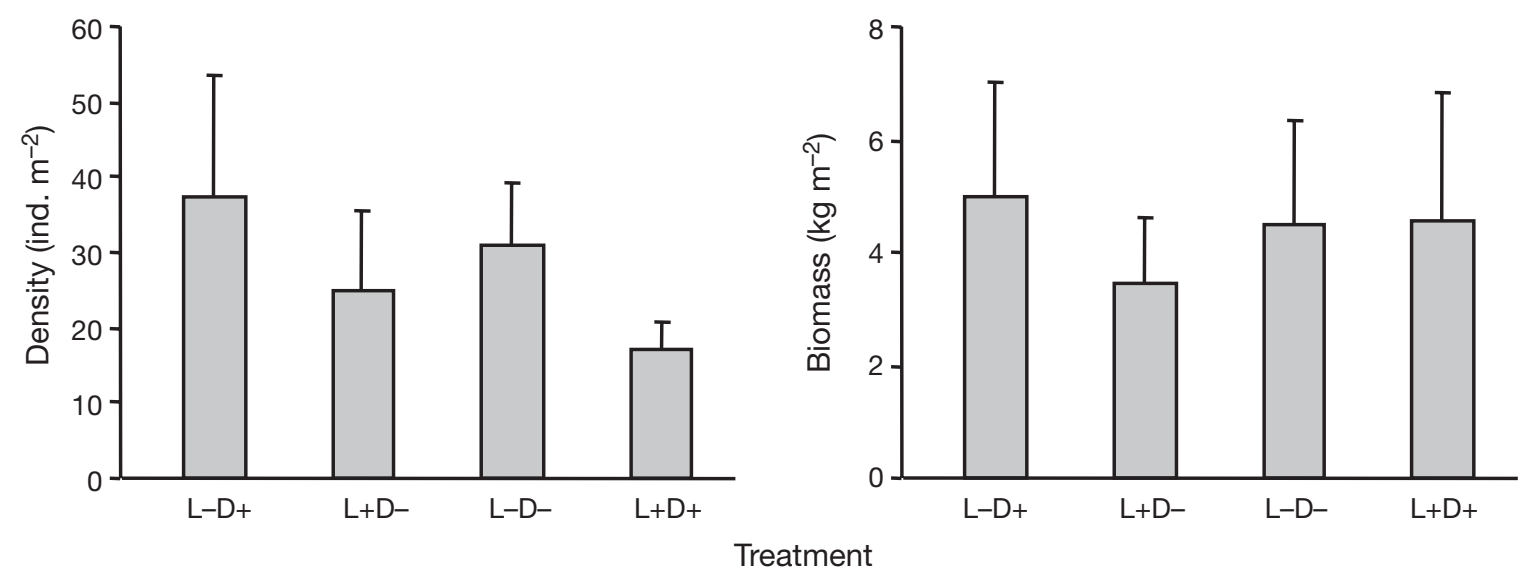

Fig. 2. Codium fragile. Density and biomass of C. fragile in the 4 treatments at the end (August 1999) of the Laminaria spp./ Desmarestia spp. removal experiment (see Fig. 1 for explanation of treatments). Data are mean + SE for 4 replicate $1 \mathrm{~m}^{2}$ plots per treatment

of treatment on the change in mean length or circumference during either interval (2-way ANOVA, $\mathrm{p}>0.08)$. During the 1998 growing season (between May and October) however, there was a significant effect of Laminaria on the change in both length $\left(F_{1,67}=5.3, \mathrm{p}=\right.$ $0.025)$ and circumference $\left(F_{1,67}=10.5, \mathrm{p}=\right.$ 0.002 ), with increases occurring only in treatments without kelp (Fig. 4). There was no effect of Desmarestia on either measure ( $p>0.50)$, and no interaction between Laminaria and Desmarestia ( $p$ > 0.30). During winter 1998-1999 (between October and February), the size of Codium decreased in all treatments except the control. There were no significant treatment effects on the change in length (log-transformed data, $p>0.08$ ), but a significant effect of Laminaria on change in circumference $\left(F_{1,67}=3.17\right.$, $\mathrm{p}=0.025)$, with decreases in treatments without Laminaria but not in those with kelp present. There was no effect of Desmarestia on change in circumference of Codium ( $p>0.40)$, and no interaction between Laminaria and Desmarestia ( $p>0.70$ ). During the 1999 growing season (June to August), the size of Codium increased again with no effect of treatment $(p>$ 0.25). A similar result was obtained when the interval was extended from February to August 1999. Maximum growth rates of individual thalli (standardized per month during each growing season) were 12.0, 11.1 and $9.6 \mathrm{~cm} \mathrm{mo}^{-1}$ in 1997, 1998 and 1999, respectively.

Survival rate of marked plants, pooled across plots within treatments, was high in all treatments after the first year (85 to $100 \%$ of the initial number in October 1998) and did not differ between treatments (2-way contingency table,
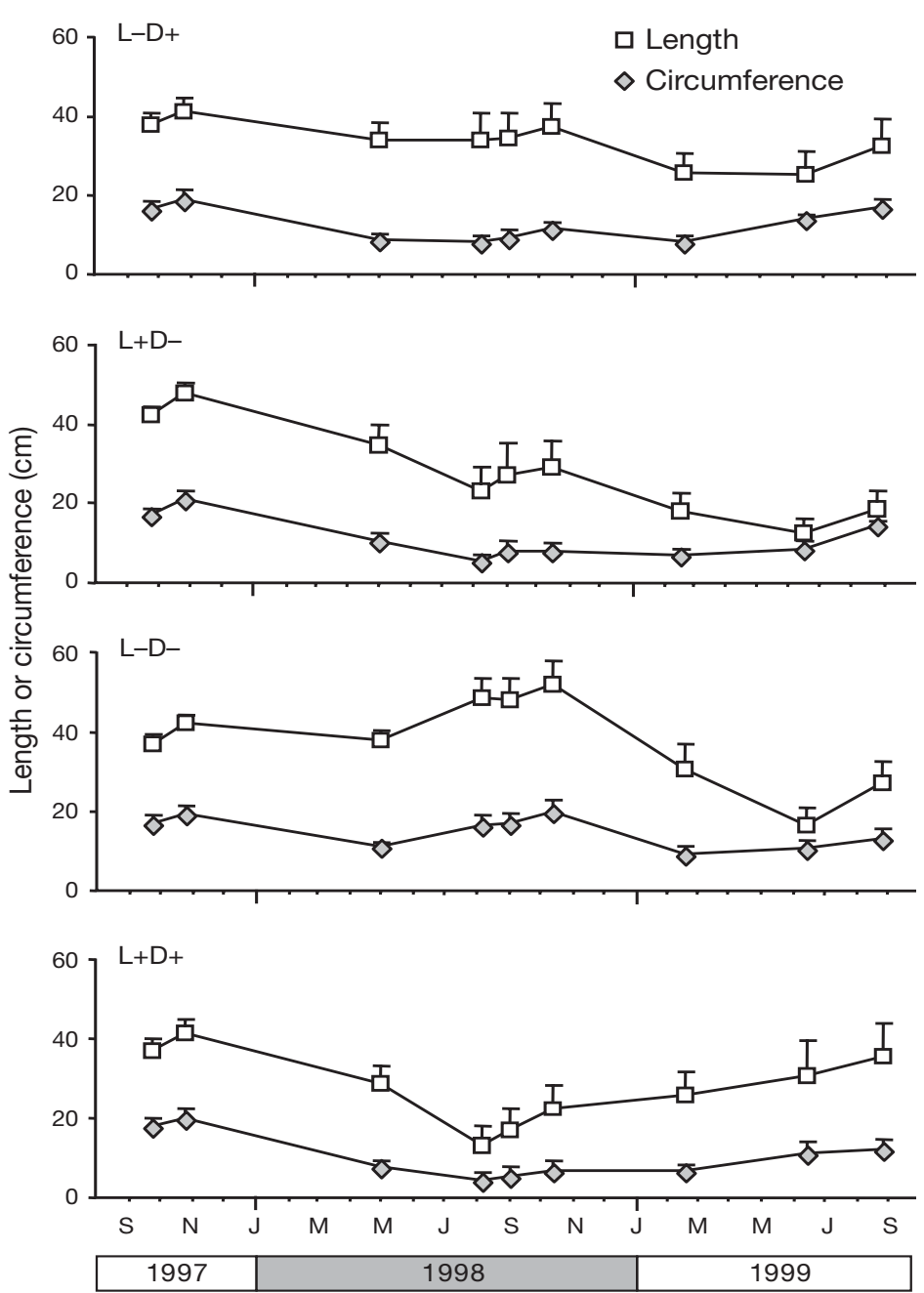

Fig. 3. Codium fragile. Change in length and circumference of marked plants over a 2 yr period (September 1997 to August 1999) in the 4 treatments in the Laminaria spp./Desmarestia spp. removal experiment (see Fig. 1 for explanation of treatments). Data are mean + SE. Plants were pooled over 4 replicate $1 \mathrm{~m}^{2}$ plots within each treatment ( $\mathrm{n}=8$ to 22 ) 
$\left.\chi^{2}{ }_{3}=3.08, p=0.379\right)$. Survivors included plants that were temporarily lost (presumably due to dislodgment by wave action) during an interval, but later re-grew from a basal holdfast or residual filaments, and therefore were counted in subsequent intervals. This occurred in 18 out of the 81 cases (10 in May, 8 in July) or $22 \%$ of marked plants. Survival rate appeared to decrease markedly in all treatments during the second year (to $40-60 \%$ by August 1999). However, estimates of survival in 1999 may have been confounded by a decreased relocation rate of markers (due to overgrowth by coralline algae), particularly by June 1999 (21 markers not found). Also, some of the 14 plants that were recorded as lost in June (i.e. the marker was found but the plant was missing or reduced to a holdfast) may have regenerated after August, had the experiment not ended then. Survival rate of relocated plants at the end of the experiment did not differ between treatments $\left(\chi^{2}{ }_{3}=0.95, \mathrm{p}=0.813\right)$.

\section{Dense stands of Codium fragile inhibit recolonization of native canopy species}

The Pulse removal of Codium in August 1997, and again in the same plots in July 1998, resulted in increases in the cover of Laminaria (mainly juveniles that could not be resolved to species) and Desmarestia (exclusively $D$. viridis) relative to the control (Fig. 5). Repeated measures ANOVA of percentage cover of each native species/genus (arcsin-transformed data) from April to July 1998 (8 to 12 mo after the first Pulse treatment) showed significant effects of treatment (Laminaria: $F_{1,8}=14.5, \mathrm{p}=0.005 ;$ Desmarestia: $F_{1,8}=$ 22.9, $\mathrm{p}=0.001$ ) and date (Laminaria: $F_{1.1,8.8}=6.2, \mathrm{p}=$

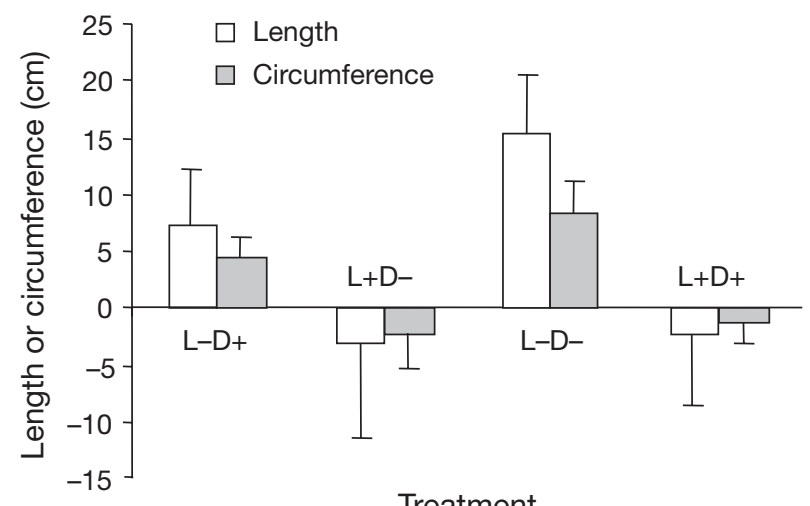

Treatment

Fig. 4. Codium fragile. Change in length and circumference of marked plants over a 5.5 mo period (1 May 1998 to 14 October 1998) in the 4 treatments in the Laminaria spp./Desmarestia spp. removal experiment (see Fig. 1 for explanation of treatments). Data are mean + SE for plants pooled over 4 replicate $1 \mathrm{~m}^{2}$ plots within each treatment ( $\mathrm{n}=16$ to 20 )
0.033; Desmarestia: $\left.F_{2,16}=46.9, \mathrm{p}<0.001\right)$. There was no interaction of treatment and date for Laminaria $\left(F_{1.1,8.8}=1.8, \mathrm{p}=0.212\right)$; the interaction was significant for Desmarestia $\left(F_{2,16}=21.7, \mathrm{p}<0.001\right)$ due to changes in the magnitude of the difference between treatments over time.

Similar results were obtained over 1 yr after the second Pulse (July 1998 to August 1999, excluding August 1998 because of missing data) when the Press treatment was included in the analysis: there were significant effects of treatment (Laminaria: $F_{2,12}=4.80, \mathrm{p}=$ 0.029; Desmarestia: $F_{2,12}=14.8 \mathrm{p}=0.001$ ) and date (Laminaria: $F_{2.3,27.3}=4.00, \mathrm{p}=0.026 ;$ Desmarestia: $\left.F_{2.2,26.1}=34.5, \mathrm{p}<0.001\right)$ and a significant interaction between treatment and date (Laminaria: $F_{4.6,27.3}=$ 4.19, $\mathrm{p}=0.007$; Desmarestia: $F_{4.3,26.1}=10.9, \mathrm{p}<0.001$ ). Post hoc tests indicated that canopy cover of both Laminaria and Desmarestia was significantly greater in the 2 Codium removal treatments than in the control $(p<0.05)$, but did not differ significantly between the Press and Pulse treatments.

At the end of the experiment (August 1999), Laminaria was virtually absent in the control plots (Fig. 6), resulting in highly significant differences among treatments (1-way ANOVA, log-transformed data) for both density $\left(F_{2,12}=58.2, \mathrm{p}<0.001\right)$ and biomass $\left(F_{2,12}=35.6\right.$, $\mathrm{p}<0.001)$. Post hoc tests indicated that Laminaria density was higher in the Press than in the Pulse treatment (Tukey's test, $\mathrm{p}<0.05$ ). This was due to numerous small sporophytes in the Press treatment $(93 \%$ of plants were $<20 \mathrm{~cm}$ total length), which had accumulated over the past year, compared to the Pulse treatment with fewer small $(52 \%$ were $<20 \mathrm{~cm}$ ) and some large sporophytes (up to $180 \mathrm{~cm}$ ), which had accumulated over the past 2 yr since the initial Pulse removal of Codium. Differences in sporophyte size among replicate plots of the Pulse removal treatment resulted in high withintreatment variability in biomass. Consequently, biomass of Laminaria did not differ significantly between the Pulse and Press treatments ( $p>0.05)$, although on average it was 3 times greater in the Pulse treatment. The annual kelp Saccorhiza dermatodea was most abundant (but patchy) in the Press treatment (Fig. 6), although among treatment differences were significant only for biomass (1-way ANOVA, log-transformed data: $\left.F_{2,12}=5.45, \mathrm{p}=0.021\right)$ and not density $\left(F_{2,12}=2.65, \mathrm{p}=\right.$ 0.112). Post hoc tests indicated that biomass of $S$. dermatodea did not differ significantly $(\mathrm{p}=0.071)$ between removal treatments, both of which had a greater biomass than the control $(\mathrm{p}<0.05)$. Desmarestia viridis occurred only in the Press removal treatment (Fig. 6).

In the Pulse removal treatment, the density and biomass of Codium (Fig. 7) were significantly higher in August 1999 (1 yr after the second Pulse removal) than in July 1998 (1 yr after the first Pulse removal) (paired 

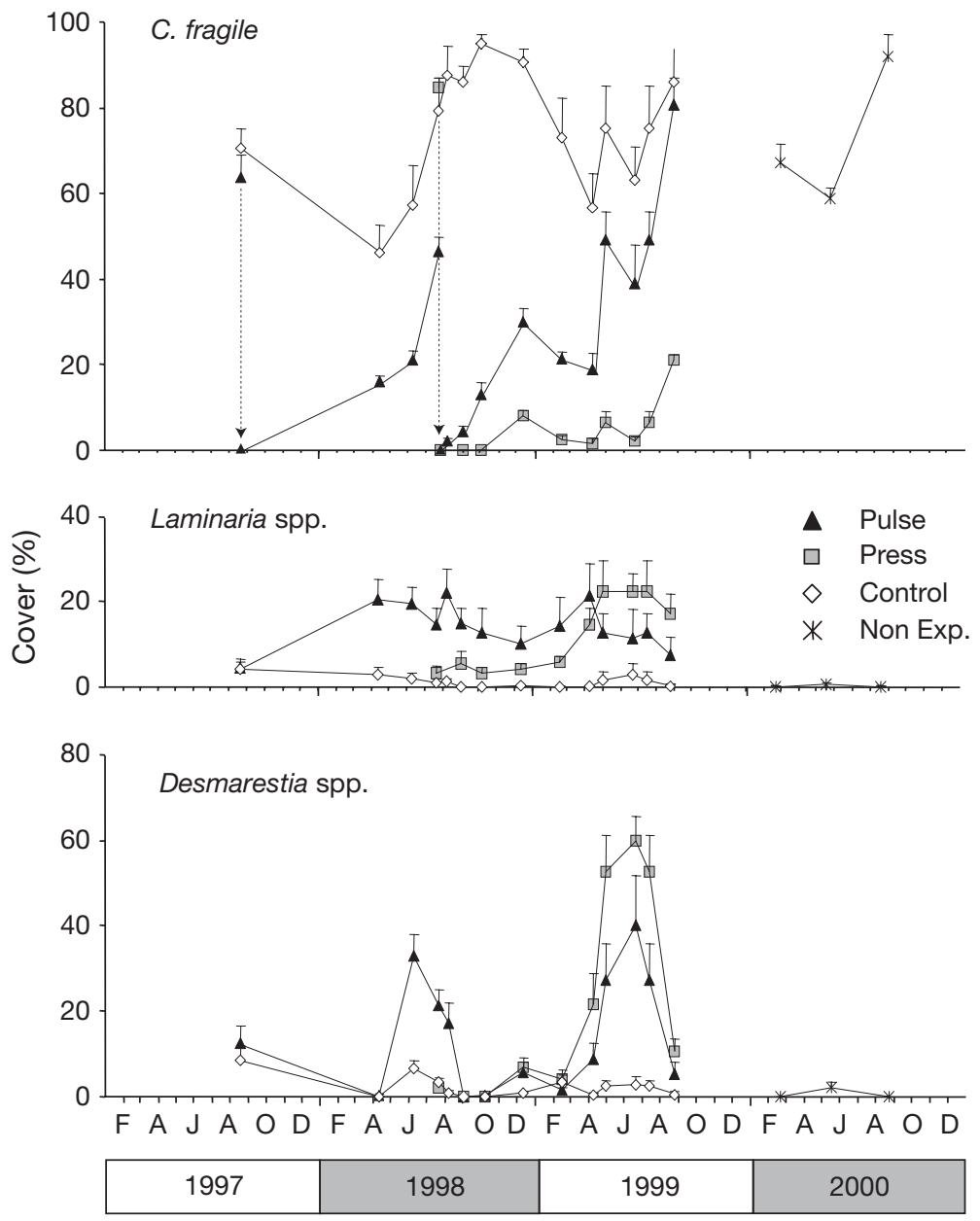

Fig. 5. Codium fragile, Laminaria spp. and Desmarestia spp. Change in percentage canopy cover of algae in 2 treatments in which Codium was experimentally removed (Pulse: a single pulse removal in August 1997 and again in July 1998 - indicated by the 2 arrows; Press: continued removal from July 1998 - indicated by the right arrow - to August 1999) and in an unmanipulated control. Also shown is canopy cover of each species in the natural assemblage (Non Exp., non-experimental random samples) from February to August 2000. Data are mean $+\mathrm{SE}$ for 5 replicate $1 \mathrm{~m}^{2}$ plots per treatment (10 plots for the non-experimental random samples)

samples $t$-test: density, $t_{3}=10.6, \mathrm{p}<0.001$; biomass, $t_{3}=$ 2.9, $\mathrm{p}<0.030$ ). In July 1998, the density of Codium in the Pulse removal treatment was similar to that in unmanipulated plots (measured when the Press removal treatment plots were cleared) (independent samples $t$-test: $\left.t_{6}=0.61, \mathrm{p}=0.280\right)$. However, because Pulse removal treatment consisted mainly of small plants that had recruited or re-grown over the past year, the biomass of Codium was less than half that in unmanipulated plots $\left(t_{8}=4.2, \mathrm{p}=0.001\right)$. However, in August 1999, after the second Pulse removal, neither density nor biomass of Codium differed between treatment and unmanipulated control plots (independent samples $t$-test: density, $t_{8}=0.26, \mathrm{p}=0.400$; biomass, $t_{8}=0.43, \mathrm{p}=$ 0.337). Thus the recovery of Codium after a Pulse re- moval was more rapid and complete during the second 1 yr period. The change in percentage cover of Codium (Fig. 5) shows the same pattern.

The mean size of marked Codium plants within control plots decreased over winter (between December 1998 and April 1999) by $41 \%$ in length (from $54.4 \pm 4.2$ [SE] to $31.9 \pm$ $5.3 \mathrm{~cm}$ ) and $15 \%$ in circumference (from 20.4 \pm 2.1 to $8.5 \pm 1.5 \mathrm{~cm}$ ). There was little change in these measures throughout the rest of the experiment (to August 1999). The survival rate of these marked plants was $90 \%$ after $9 \mathrm{mo.}$

\section{DISCUSSION}

Our experiments provide clear evidence that the invasive success of Codium fragile ssp. tomentosoides on the Atlantic coast of Nova Scotia is mediated by competitive interactions with native canopy-forming seaweeds (Laminaria and Desmarestia spp.). We show that Codium in Nova Scotia (1) exhibits reduced growth when associated with kelp, (2) prevents re-colonization by kelp once dense meadows are established, and (3) persists as the dominant canopy-forming seaweed for prolonged periods.

\section{Native seaweeds inhibit the growth of Codium fragile in kelp beds}

Experimental removal of Laminaria and Desmarestia at $8 \mathrm{~m}$ depth, which mimics the effects of a severe outbreak of Membranipora membranacea, demonstrated that competitive interactions with large, canopy-forming brown algae can limit the growth of Codium. Differences in the cover of Codium between treatments provide an indication of the magnitude of the effects of manipulations. These differences cannot strictly be used to infer an effect of treatment because we recorded percent cover (upper canopy surface), which results in non-independent measures of manipulated (Laminaria, Desmarestia) and response (Codium) variables. Differences between treatments in Codium cover were statistically significant in summer and fall of 1997 and 1998, when the cover was greatest in plots where both Laminaria and Desmarestia were removed. Codium cover did not differ significantly among treatments in 1999, after $M$. membranacea had naturally reduced the cover of large kelp plants and of 

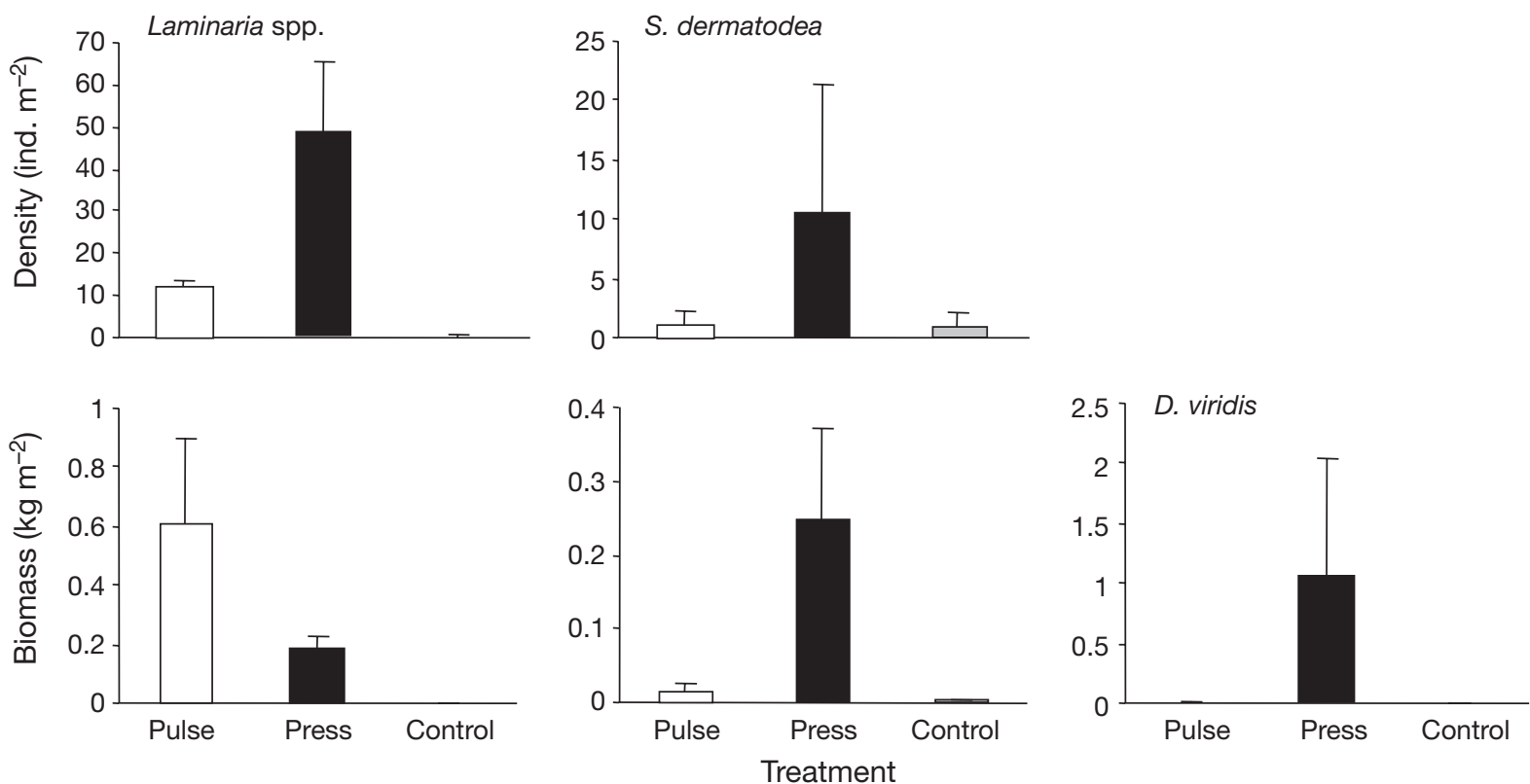

Fig. 6. Laminaria spp., Saccorhiza dermatodea and Desmarestia viridis. Algal density and biomass (D.viridis: biomass only) in the Pulse and Press removal treatments and control (see Fig. 5 for explanation of treatments) in August 1999. Data are mean + SE for 5 replicate $1 \mathrm{~m}^{2}$ plots per treatment. Note the different $y$-axis ranges between panels
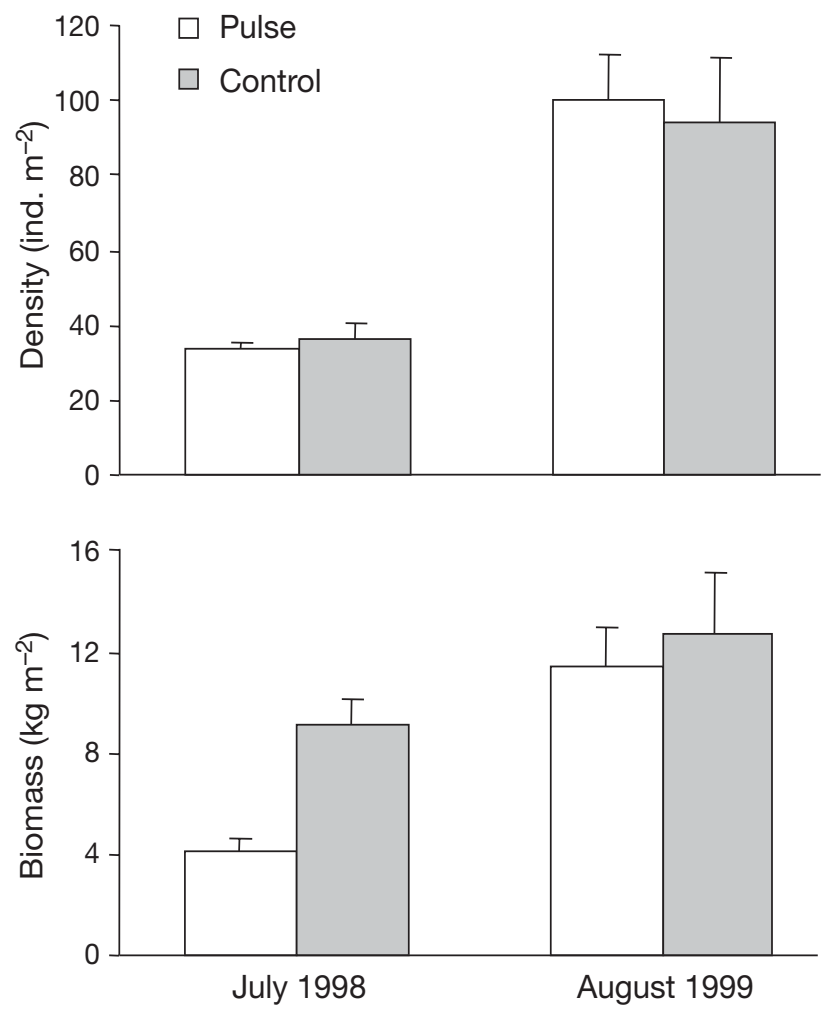

Fig. 7. Codium fragile. Density and biomass in the Pulse removal treatment and control (see Fig. 5 for explanation of treatment) in July 1998 and August 1999. Data are mean + SE for 5 replicate $1 \mathrm{~m}^{2}$ plots per treatment (except in July 1998 where 4 replicates per treatment were used to calculate Codium density)
Desmarestia in treatments where these species were not manually removed (R. E. Scheibling pers. obs.). At the end of the experiment (August 1999), there were no statistically detectable differences among treatments in either the density or biomass of Codium, although mean density was up to 2 times greater in treatments where kelp was removed than in the control. The lack of an effect at this time may reflect the reduction in the magnitude of between-treatment differences in Laminaria and Desmarestia cover in 1999, and the ability of Codium to grow rapidly in the absence of an overlying canopy (as shown in the second experiment). Although Laminaria cover (in treatments where it was not removed) was similar each summer, kelp plants were smaller in 1999 (R. E. Scheibling unpubl. data), after extensive fragmentation of the canopy the previous winter.

Large reciprocal fluctuations in the cover of Codium and Laminaria reflect between-species differences in seasonal patterns of production and loss of biomass. Codium grows most rapidly during the summer and fall, and undergoes extensive fragmentation during winter as a means of asexual propagation (Fralick \& Mathieson 1972, 1973, Bégin \& Scheibling 2003, Schmidt \& Scheibling 2006a). Increased wave action during winter storms also reduces Codium cover by detachment of whole plants, although remnants of the basal holdfast can regenerate a new thallus the following spring (Fralick \& Mathieson 1972, Trowbridge 1998, D'Amours \& Scheibling in press). In contrast, 
L. longicruris becomes nutrient limited over the summer and grows best during the cold, winter months when nutrients are readily available (Gagné et al. 1982). Kelp fronds are most heavily eroded in the fall because of tissue degeneration associated with nutrient limitation (Gagné et al. 1982), epiphytic growth of Membranipora membranacea (Scheibling et al. 1999), and grazing by the gastropod Lacuna vincta (Johnson \& Mann 1988). Asynchrony in growing seasons of kelp and Codium may favor the establishment and spread of the invasive alga during periods when kelps are most vulnerable. Seasonal differences in patterns of growth between the green alga Caulerpa taxifolia and native macrophytes (including the seagrass Posidonia oceanica) may also be important in facilitating the spread of that invasive alga in the Mediterranean (Meinesz \& Hesse 1991, Verlaque \& Fritayre 1994).

The effect of our canopy manipulations on growth of individual thalli of Codium provides strong evidence of competition with kelps. In 1998, removal of kelp (but not Desmarestia) had a positive effect on growth (thallus length and circumference) of Codium. In 1999 however, when kelps were smaller (with less of a shading effect) and Desmarestia was virtually absent, Codium grew in all treatments with no detectable differences between treatments. Within our experimental plots, maximum growth rates of individual thalli during the 1997 to 1999 growing seasons (from 9.6 to $12 \mathrm{~cm} \mathrm{mo}^{-1}$ ) exceeded the peak growth rate $\left(9.2 \mathrm{~cm} \mathrm{mo}^{-1}\right)$ of Codium in a subtidal population in New England (Fralick \& Mathieson 1973), indicating a high growth potential of Codium at our site. Other native canopyforming seaweeds and seagrasses have been shown to inhibit non-indigenous vegetation, including the kelp Undaria pinnatifida on the east coast of Tasmania (Valentine \& Johnson 2003), the brown alga Sargassum muticum along the coast of northern Spain (Andrew \& Viejo 1998), and the seagrass Posidonia oceanica along the Tuscan coasts of the northwestern Mediterranean Sea (Ceccherelli et al. 2000).

The survival rate of marked Codium plants was high in all 4 treatments in the first year (85 to $100 \%)$, but dropped during winter in the second year (40 to $60 \%$ ). The decline in survival was due mainly to the loss of the largest plants, which are more prone to fragmentation and wave dislodgment (Fralick \& Mathieson 1972, D'Amours \& Scheibling in press). This is reflected in decreases in mean thallus length of marked plants in canopy removal treatments between the fall of 1998 and the summer of 1999. This was most pronounced in the treatment without kelp or Desmarestia, and did not occur in the control, suggesting that canopy cover of native species may reduce fragmentation of Codium during winter by baffling wave surge. We probably underestimated survival of Codium at the end of the experiment because some plants recorded as lost (i.e. those reduced to a holdfast) may have regenerated, had the experiment continued. Survival curves were similar among all treatments indicating no effect of canopy manipulations on the survival of Codium.

\section{Codium meadows inhibit the re-establishment of native canopy-forming species}

Once established in shallow water at Little Duck Island in 1996, Codium expanded rapidly to accumulate a high biomass (this study, Chapman et al. 2002). The transition from dense kelp beds (mainly Laminaria digitata), which characterized this zone in the early 1990s, to a monospecific canopy (or meadow) of Codium occurred within 2 yr. Our experimental clearing of Codium at $4 \mathrm{~m}$ depth showed dense Codium meadows inhibit recruitment and growth of Laminaria and other large Phaeophyceae, such as the annuals Saccorhiza dermatodea and Desmarestia viridis. High densities of Laminaria recruits occurred in plots in which Codium was continuously cleared (Press removal treatment), indicating that spore supply was not limiting kelp recovery in this area. Some recruitment of kelps also occurred in plots where Codium was cleared once per year (Pulse removal treatment), but was limited by the rapid re-growth of Codium. Dense and bushy stands of Codium in control plots completely shaded the bottom, reduced water flow and increased sedimention, thereby effectively inhibiting recruitment of kelps and other seaweeds. Previous studies have shown a similar inhibitory effect of invasive seaweeds on recruitment of native seaweeds in press-removal experiments. In the San Juan Islands (Washington State, USA), recruitment of native understory and canopy algae (including Laminaria bongardiana) was greater in plots where the invasive brown alga Sargassum muticum was continuously removed than in control plots after $3 \mathrm{yr}$ (Britton-Simmons 2004). In the Mediterranean Sea, total cover and species richness of native vegetation were greater after $1 \mathrm{yr}$ in plots where the invasive green alga Caulerpa racemosa was removed than in unmanipulated plots (Piazzi \& Ceccherelli 2006).

Codium regenerated rapidly in our Pulse clearings. After $12 \mathrm{mo}$, density in cleared plots did not differ significantly from controls, suggesting that thalli (manually removed by plucking them from the bottom) regenerated from basal holdfasts. Vegetative regrowth from holdfasts was evident (particularly during summer months) in the Press removal treatment, where regenerating plants were removed on a monthly basis. In the second Pulse clearing, cover and 
biomass of Codium after 12 mo also matched that of controls, showing complete recovery of Codium in metre-scale gaps within a year. Regeneration and rapid growth of Codium from basal parts or holdfasts confers a competitive advantage over recruits of kelp and other native seaweeds. Once established in dense meadows, Codium appears to be resilient to localized disturbances, such as wave dislodgment. Sargassum muticum exhibits a similar capacity for rapid recovery from disturbance that promotes its competitive displacement of native seaweeds (Deysher \& Norton 1982, de Wreede 1983). Cover of Codium within unmanipulated plots remained high throughout our experiment (with cyclical, phenological decreases and increases), indicating persistence in the absence of major disturbance. This contrasts with the situation in Limfjorden (Denmark), where established stands of Codium were competitively displaced by expanding populations of S. muticum between 1990 and 1997 (Staehr et al. 2000).

A significant element of the invasion success of Codium is opportunistic exploitation of disturbancegenerated gaps within native kelp beds created by Membranipora membranacea. Heathly kelp beds appear to resist Codium, but heavy infestations of the bryozoan can cause total defoliation of kelp over vast tracks of seabed (Scheibling et al. 1999, Chapman et al. 2002, R. E. Scheibling unpubl. data). Desmarestia aculeata also can be entirely encrusted by $M$. membranacea (Harris \& Tyrrell 2001, R. E. Scheibling pers. obs.) and may erode in the same way. We have rarely seen M. membranacea on Codium in Nova Scotia, and then only as relatively small colonies on the older basal sections of the thallus, although high infestation rates have been reported in the Gulf of Maine (up to $76 \%$ of Codium plants with M. membranacea; Harris \& Tyrrell 2001). No effect of $M$. membranacea on thallus fragmentation has been reported for Codium. By disproportionately affecting native canopy species, the epiphytic bryozoan not only provides Codium with an opportunity for invasion, but also a competitive edge over native species once the alien is established.

\section{CONCLUSIONS AND FUTURE RESEARCH DIRECTIONS}

In Nova Scotian kelp beds, Laminaria longicruris and $L$. digitata form dense perennial canopies that effectively shade the bottom and limit the growth of smaller understory species (Johnson \& Mann 1988). Other canopy-forming seaweeds, such as Desmarestia aculeata and $D$. viridis and the annual kelp Saccorhiza dermatodea, typically occupy gaps in a healthy kelp canopy (Scheibling 1986, Scheibling et al. 1999). Luxu- riant kelp beds appear to have inhibited the establishment of Codium until they were destroyed by recurrent infestations of Membranipora membranacea in the mid to late 1990s (Scheibling et al. 1999, Chapman et al. 2002). Our experimental results support this conclusion by showing that growth of Codium is limited by a kelp canopy. Once this canopy is removed and Codium expands to form dense meadows, the invasive alga prevents re-colonization by kelp and persists as the dominant canopy-forming seaweed for prolonged periods. Other factors contributing to the invasive success of Codium in Nova Scotia may include intense recruitment via dispersing propagules and vegetative production of new thalli (Schmidt \& Scheibling 2005), a broad tolerance to physiological stressors (Bégin \& Scheibling 2003, Schmidt \& Scheibling 2005), morphological plasticity in response to wave climate (Bégin \& Scheibling 2003, D'Amours \& Scheibling in press), and low palatability to generalist herbivores such as the sea urchin Strongylocentrotus droebachiensis (Sumi \& Scheibling 2005).

As outlined by Crooks (2002), exotic species can affect ecosystems by altering a number of ecosystem components, including the quality and quantity of food, and physical resources such as living space. An expanding body of experimental and correlational evidence suggests that Codium could exert significant bottom-up forcing on subtidal communities of the northwest Atlantic (Berman et al. 1992, Harris \& Tyrrell 2001, Levin et al. 2002, Mathieson et al. 2003). Additional quantitative studies are required to assess the impacts of Codium on the structure and function of native communities at various spatial scales (Schmidt \& Scheibling 2006a,b), and the extent to which such impacts are accelerated by interactions between multiple invaders such as Membranipora membranacea and Paramoeba invadens, the pathogenic agent of urchin mass mortality (Chapman et al. 2002).

The invasion success of Codium in the northwest Atlantic, like that of the kelp Undaria pinnatifida in Tasmania (Valentine \& Johnson 2003) and Sargassum muticum in the northeast Pacific (Britton-Simmons $2004,2006)$, is contingent on disturbance to native canopy species that otherwise preempt space. Indeed, disturbance can play a central role in the invasion ecology of many species (Hobbs \& Huenneke 1992, Alpert et al. 2000), and identifying and ameliorating disturbances whenever possible (e.g. anthropogenic impacts) may preclude or diminish invasions at an early stage of development. Currently, C. fragile ssp. tomentosoides, Membranipora membranacea, and Paramoeba invadens are limited to regions below southern Québec. This may be related to suboptimal conditions for recruitment and survival, a lack of vectors (although commercial and recreational vessels regularly transit 
between the southern and northern Gulf of St. Lawrence), or biotic resistance of northern subtidal communities, which differ somewhat in structure and organization from communities in more southern regions, like Nova Scotia (Scheibling et al. 1999, Chapman et al. 2002, Gagnon et al. 2004, Gagnon et al. 2005). A broader understanding of factors that determine the success of Codium in its invaded range, such as competitive and facilitative interactions with introduced and native species, will aid in predicting the future expansion of this highly invasive species.

Acknowledgements. We are indebted to T. Balch, A. Hennigar, I. Dempsey, and the many other divers who helped with field work, and to R. Melady and S. Brady for assistance with data analysis and graphics. We thank A. Metaxas, D. Lyons, J.-S. Lauzon-Guay and 3 anonymous reviewers for their comments on earlier drafts of the manuscript. This research was supported by a Natural Sciences and Engineering Research Council of Canada (NSERC) Discovery Grant to R.E.S.

\section{LITERATURE CITED}

Alpert P, Bone E, Holzapfel C (2000) Invasiveness, invasibility and the role of environmental stress in the spread of nonnative plants. Perspect Plant Ecol Evol Syst 3:52-66

Andrew NL, Viejo RM (1998) Ecological limits to the invasion of Sargassum muticum in northern Spain. Aquat Bot 60:251-263

Balata D, Piazzi L, Cinelli F (2004) A comparison among assemblages in areas invaded by Caulerpa taxifolia and C. racemosa on a subtidal Mediterranean rocky bottom. PSZN I: Mar Ecol 25:1-13

Balch T, Scheibling RE (2000) Temporal and spatial variability in settlement and recruitment of echinoderms in kelp beds and barrens in Nova Scotia. Mar Ecol Prog Ser 205: 139-154

Bax N, Williamson A, Aguero M, Gonzalez E, Geeves W (2003) Marine invasive alien species: a threat to global biodiversity. Mar Policy 27:313-323

Bégin C, Scheibling RE (2003) Growth and survival of the invasive green alga Codium fragile ssp. tomentosoides in tide pools on a rocky shore in Nova Scotia. Bot Mar 46: 404-412

Berman J, Harris L, Lambert W, Buttrick M, Dufresne M (1992) Recent invasions of the Gulf of Maine: three contrasting ecological histories. Conserv Biol 6:435-441

Bird CJ, Dadswell MJ, Grund DW (1993) First record of the potential nuisance alga Codium fragile ssp. tomentosoides (Chlorophyta, Caulerpales) in Atlantic Canada. Proc N S Inst Sci 40:11-17

Boudouresque CF, Verlaque M (2002) Biological pollution in the Mediterranean Sea: invasive versus introduced macrophytes. Mar Pollut Bull 44:32-38

Britton-Simmons KH (2004) Direct and indirect effects of the introduced alga Sargassum muticum on benthic, subtidal communities of Washington State, USA. Mar Ecol Prog Ser 277:61-78

Britton-Simmons KH (2006) Functional group diversity, resource preemption and the genesis of invasion resistance in a community of marine algae. Oikos 113:395-401

Bruno JF, Bertness MD (2001) Habitat modification and facilitation in benthic marine communities. In: Bertness MD,
Gaines SD, Hay ME (eds) Marine community ecology. Sinauer Associates, Sunderland, p 201-218

Buschbaum C, Chapman AS, Saier B (2006) How an introduced seaweed can affect epibiota diversity in different coastal systems. Mar Biol 148:743-754

Callaway RM (1995) Positive interactions among plants. Bot Rev 61:306-349

Carlton JT (1992) Introduced marine and estuarine mollusks of North America: an end-of-the-20th-century perspective. J Shellfish Res 11:489-505

Carlton JT (1999) Scale and ecological consequences of biological invasions in the world's oceans. In: Sandlund OT, Schei PJ, Viken A (eds) Invasive species and biodiversity management. Kluwer Academic Publisher, Dordrecht, p 195-212

Carlton JT, Scanlon JA (1985) Progression and dispersal of an introduced alga: Codium fragile ssp. tomentosoides (Chlorophyta) on the Atlantic coast of North America. Bot Mar 28:155-165

Casas G, Scrosati R, Piriz ML (2004) The invasive kelp Undaria pinnitifida (Phaeophyceae, Laminariales) reduces native seaweed diversity in Nuevo Gulf (Patagonia, Argentina). Biol Invasions 6:411-416

Castilla JC, Uribe M, Bahamonde N, Clarke M and 7 others (2005) Down under the southeastern Pacific: marine nonindigenous species in Chile. Biol Invasions 7:213-232

Ceccherelli G, Piazzi L, Cinelli F (2000) Response of the nonindigenous Caulerpa racemosa (Forsskal) J. Agardh to the native seagrass Posidonia oceanica (L.) Delile: effect of density of shoots and orientation of edges of meadows. J Exp Mar Biol Ecol 243:227-240

Chapman AS (1999) From introduced species to invader: What determines variation in the success of Codium fragile ssp. tomentosoides (Chlorophyta) in the North Atlantic Ocean? Helgol Meeresunters 52:277-289

Chapman AS, Scheibling RE, Chapman ARO (2002) Species introductions and changes in marine vegetation of Atlantic Canada. In: Claudi R, Nantel P, Muckle-Jeffs E (eds) Alien invaders in Canada's waters, wetlands and forests. Natural Resources Canada, Canadian Forest Service Science Branch, Ottawa, p 133-148

Cohen AN, Carlton JT (1998) Accelerating invasion rate in a highly invaded estuary. Science 279:555-558

Crooks JA (2002) Characterizing ecosystem-level consequences of biological invasions: the role of ecosystem engineers. Oikos 97:153-166

D'Amours O, Scheibling RE (in press) Effect of wave exposure on morphology, attachment strength and survival of the invasive green alga Codium fragile ssp. tomentosoides. J Exp Mar Biol Ecol

de Wreede RE (1983) Sargassum muticum (Fucales, Phaeophyta): regrowth and interaction with Rhodomela larix (Ceraminales, Rhodophyta). Phycologia 22:153-160

Deysher LE, Norton TA (1982) Dispersal and colonisation in Sargassum muticum (Yendo) Fensholt. J Exp Mar Biol Ecol 56:179-195

Elton CS (1958) The ecology of invasions by animals and plants. Methuen, London

Fralick RA, Mathieson AC (1972) Winter fragmentation of Codium fragile (Suringar) Hariot ssp. tomentosoides (van Goor) Silva (Chlorophyceae, Siphonales) in New England. Phycologia 11:67-70

Fralick RA, Mathieson AC (1973) Ecological studies of Codium fragile in New England, USA. Mar Biol 19: $127-132$

Gagné JA, Mann KH, Chapman ARO (1982) Seasonal patterns of growth and storage in Laminaria longicruris in 
relation to differing patterns of availability of nitrogen in the water. Mar Biol 69:91-101

Gagnon P, Himmelman JH, Johnson LE (2004) Temporal variation in community interfaces: kelp-bed boundary dynamics adjacent to persistent urchin barrens. Mar Biol 144: 1191-1203

Gagnon P, Johnson LE, Himmelman JH (2005) Kelp patch dynamics in the face of intense herbivory: stability of Agarum clathratum (Phaeophyta) stands and associated flora on urchin barrens. J Phycol 41:498-505

Garbary DJ, Vandermeulen H, Kim KY (1997) Codium fragile ssp. tomentosoides (Chlorophyta) invades the Gulf of St Lawrence, Atlantic Canada. Bot Mar 40:537-540

Grosholz ED, Ruiz GM (1996) Predicting the impact of introduced marine species: lessons from the multiple invasions of the European green crab Carcinus maenas. Biol Conserv 78:59-66

Grosholz ED, Ruiz GM, Dean CA, Shirley KA, Maron JL, Connors PG (2000) The impacts of a nonindigenous marine predator in a California bay. Ecology 81:1206-1224

Harris LG, Tyrrell MC (2001) Changing community states in the Gulf of Maine: synergism between invaders, overfishing and climate change. Biol Invasions 3:9-21

Hobbs RJ, Huenneke LF (1992) Disturbance, diversity, and invasions: implications for conservation. Conserv Biol 6: 324-337

Jaubert JM, Chisholm JRM, Minghelli-Roman A, Marchioretti M, Morrow JH, Ripley HT (2003) Re-evaluation of the extent of Caulerpa taxifolia development in the northern Mediterranean using airborne spectrographic sensing. Mar Ecol Prog Ser 263:75-82

Johnson CR, Mann KH (1988) Diversity, patterns of adaptation, and stability of Nova Scotian kelp beds. Ecol Monogr 58:129-154

Kushner RB, Hovel KA (2006) Effects of native predators and eelgrass habitat structure on the introduced Asian mussel Musculista senhousia (Benson in Cantor) in southern California. J Exp Mar Biol Ecol 332:166-177

Lambert WJ, Levin PS, Berman J (1992) Changes in the structure of a New England (USA) kelp bed: the effects of an introduced species? Mar Ecol Prog Ser 88:303-307

Levin PS, Coyer JA, Petrik R, Good TP (2002) Communitywide effects of nonindigenous species on temperate rocky reefs. Ecology 83:3182-3193

MacIsaac HJ (1996) Potential abiotic and biotic impacts of zebra mussels on the inland waters of North America. Am Zool 36:287-299

Mathieson AC, Dawes CJ, Harris LG, Hehre EJ (2003) Expansion of the Asiatic green alga Codium fragile subsp. tomentosoides in the Gulf of Maine. Rhodora 105:1-53

Meidel SK, Scheibling RE (1998) Annual reproductive cycle of the green sea urchin, Strongylocentrotus droebachiensis, in differing habitats in Nova Scotia, Canada. Mar Biol 131: $461-478$

Meinesz A, Hesse B (1991) Introduction et invasion de l'algue tropicale Caulerpa taxifolia en Méditerranée nordoccidentale. Oceanol Acta 14:415-426

Parker JD, Burkepile DE, Hay ME (2006) Opposing effects of native and exotic herbivores on plant invasions. Science 311:1459-1461

Piazzi L, Ceccherelli G (2006) Persistence of biological invasion effects: recovery of macroalgal assemblages after removal of Caulerpa racemosa var. cylindracea. Estuar Coast Shelf Sci 68:455-461

Posey MH (1988) Community changes associated with the spread of an introduced seagrass, Zostera japonica. Ecology 69:974-983
Reusch TBH, Williams SL (1999) Macrophyte canopy structure and the success of an invasive marine bivalve. Oikos 84:398-416

Ribera MA, Boudouresque CF (1995) Introduced marine plants, with special reference to macroalgae: mechanisms and impact. In: Round FE, Chapman DJ (eds) Progress in phycological research, Vol 11. Biopress, Bristol, p 187-268

Ricciardi A (2001) Facilitative interactions among aquatic invaders: Is an 'invasional meltdown' occuring in the Great Lakes? Can J Fish Aquat Sci 58:2513-2525

Ruiz GM, Carlton JT, Grosholz ED, Hines AH (1997) Global invasions of marine and estuarine habitats by non-indigenous species: mechanisms, extent, and consequences. Am Zool 37:621-632

Ruiz GM, Fofonoff PW, Carlton JT, Wonham MJ, Hines AH (2000) Invasion of coastal marine communities in North America: apparent patterns, processes, and biases. Annu Rev Ecol Syst 31:481-531

Sanchez I, Fernandez C, Arrontes J (2005) Long-term changes in the structure of intertidal assemblages after invasion by Sargassum muticum (Phaeophyta). J Phycol 41:942-949

Scheibling RE (1986) Increased macroalgal abundance following mass mortalities of sea urchins (Strongylocentrotus droebachiensis) along the Atlantic coast of Nova Scotia. Oecologia 68:186-198

Scheibling RE, Anthony SX (2001) Feeding, growth and reproduction of sea urchins (Strongylocentrotus droebachiensis) on single and mixed diets of kelp (Laminaria spp.) and the invasive alga Codium fragile ssp. tomentosoides. Mar Biol 139:139-146

Scheibling RE, Hennigar AW (1997) Recurrent outbreaks of disease in sea urchins Strongylocentrotus droebachiensis in Nova Scotia: evidence for a link with large-scale meteorologic and oceanographic events. Mar Ecol Prog Ser 152:155-165

Scheibling RE, Hennigar AW, Balch T (1999) Destructive grazing, epiphytism, and disease: the dynamics of sea urchin-kelp interactions in Nova Scotia. Can J Fish Aquat Sci 56:2300-2314

Schmidt AL, Scheibling RE (2005) Population dynamics of an invasive green alga, Codium fragile subsp. tomentosoides, in tidepools on a rocky shore in Nova Scotia, Canada. Écoscience 12:403-411

Schmidt AL, Scheibling RE (2006a) Effects of native (Laminaria spp.) and invasive (Codium fragile ssp. tomentosoides) macroalgal canopies on composition and abundance of mobile benthic macrofauna and turf-forming algae. J Exp Mar Biol Ecol (in press)

Schmidt AL, Scheibling RE (2006b) A comparison of epifauna and epiphytes on native kelps (Laminaria species) and an invasive alga (Codium fragile ssp. tomentosoides) in Nova Scotia, Canada. Bot Mar 49:315-330

Simberloff D, Von Holle B (1999) Positive interactions of nonindigeneous species: invasional meltdown? Biol Invasions $1: 21-32$

Stachowicz JJ, Whitlatch RB, Osman RW (1999) Species diversity and invasion resistance in a marine ecosystem. Science 286:1577-1579

Staehr PA, Pedersen MF, Thomsen MS, Wernberg T, KrauseJensen D (2000) Invasion of Sargassum muticum in Limfjorden (Denmark) and its possible impact on the indigenous macroalgal community. Mar Ecol Prog Ser 207:79-88

Strayer DL, Hattala KA, Kahnle AW (2004) Effects of an invasive bivalve (Dreissena polymorpha) on fish in the Hudson River estuary. Can J Fish Aquat Sci 61:924-941

Sumi CBT, Scheibling RE (2005) Role of grazing by sea 
urchins Strongylocentrotus droebachiensis in regulating the invasive alga Codium fragile ssp. tomentosoides in Nova Scotia. Mar Ecol Prog Ser 292:203-212

Trowbridge CD (1998) Ecology of the green macroalga Codium fragile (Suringar) Hariot 1889: invasive and noninvasive subspecies. In: Ansell AD, Gibson RN, Barnes $M$ (eds) Oceanography and marine biology, an annual review, Vol 36. UCL Press, London, p 1-64

Valentine JP, Johnson CR (2003) Establishment of the introduced kelp Undaria pinnatifida in Tasmania depends on disturbance to native algal assemblages. J Exp Mar Biol Ecol 295:63-90

Verlaque M (1994) Inventaire des plantes introduites en

Editorial responsibility: Otto Kinne (Editor-in-Chief), Oldendorf/Luhe, Germany
Méditerranée: origines et répercussions sur l'environnement et les activités humaines. Oceanol Acta 17:1-23

Verlaque M, Fritayre P (1994) Modifications des communautés algales méditerranéennes en présence de l'algue envahissante Caulerpa taxifolia (Vahl) C. Agardh. Oceanol Acta 17:659-672

Wonham MJ, O'Connor M, Harley CDG (2005) Positive effects of a dominant invader on introduced and native mudflat species. Mar Ecol Prog Ser 289:109-116

York PH, Booth DJ, Glasby TM, Pease BC (2006) Fish assemblages in habitats dominated by Caulerpa taxifolia and native seagrasses in south-eastern Australia. Mar Ecol Prog Ser 312:223-234

Submitted: July 28, 2006; Accepted: September 28, 2006 Proofs received from author(s): October 13, 2006 